\title{
Factor Affecting Customers' Decision to Use Mobile Banking Service: A Case of Thanh Hoa Province, Vietnam
}

\author{
Hoang Ba Huyen LE ${ }^{*}$, Chi Thanh NGO**, Thi Thu Huyen TRINH ${ }^{* * *}$ \\ Thi Thu Phuong NGUYEN ${ }^{* * * *}$
}

Received: November 24, 2019 Revised: December 11, 2019 Accepted: December 18, 2019

\begin{abstract}
The article aims to identify the main factors affecting customers' decision to use mobile banking service in Vietnam, a case study in Thanh Hoa province. Based on theoretical frameworks of the Technology Acceptance Model (TAM) and the Unified Theory of Acceptance and Use of Technology (UTAUT), the study has been conducted with 370 questionnaires to consumers who have not yet used and are currently using mobile banking in Thanh Hoa province. The research results indicates that several factors have been evaluated to be more important than others, of which, the social influence is the strongest, the second is the compatibility and some others factors such as perceived ease of use, perceived trust, etc., all affecting the intention to use mobile banking in Thanh Hoa. Based on these important results, the article propose a number of recommendations: (i) Exploiting the advantages of social influence on the increase of intention to use; (ii) Increasing compatibility and minimizing costs for customers when they use Mobile Banking; (iii) Developing a strategy to increase the users' perceived ease of using banking services; (iv) Issuing a policy on increasing the security of Mobile Banking system to meet customers' needs; and (v) Developing an individual customer management system to improve service quality.
\end{abstract}

Keywords: Affecting Factors, Customers' Decision, Mobile Banking, Thanh Hoa Province, Vietnam.

JEL Classification Code: M31, M37, D7, C5

\section{Introduction}

Mobile Banking is a modern banking service channel provided by a bank that allows its customers to use their Internet-connected smartphones/tablets to conduct banking transactions. This is a channel, through which customers can interact with a bank via a smartphone or a Personal Digital

*First Author and Corresponding Author. Dean, Faculty of Economics and Business Administration, Hong Duc University, Vietnam [Postal Address: No 565, Quang Trung Street, Dong Ve Ward, Thanh Hoa City, Thanh Hoa Province, 40000-42000, Vietnam] Tel. (84) 912.222.345,

Email: lehoangbahuyen@hdu.edu.vn

**Lecturer, Head of Technology and Science Management Department, Hong Duc University, Vietnam.

Email: ngochithanh@hdu.edu.vn

***Lecturer, Faculty of Economics and Business Administration, Hong Duc University, Vietnam. Email: trinhthithuhuyen@hdu.edu.vn ****Lecturer, Faculty of Economics and Business Administration, Hong Duc University, Vietnam.

Email: nguyenthithuphuong@hdu.edu.vn

$\odot$ Copyright: Korean Distribution Science Association (KODISA)

This is an Open Access article distributed under the terms of the Creative Commons Attribution NonCommercial License (https://creativecommons.org/licenses/by-nc/4.0/) which permits unrestricted noncommercial use, distribution, and reproduction in any medium, provided the original work is properly cited.
Assistant (PDA) (Barnes \& Cobitt, 2003). For banks, mobile banking helps to get higher income, larger market, save more money and stronger in competitiveness. For customers; it provides such benefits as account management, bank transfer, bill payment and so forth, helping to save costs and time. Therefore, mobile banking has become an indispensable trend in the development of the banking industry.

Later applying than other customers in the world, Vietnam has about a half of the population exposed to the Internet and up to $70 \%$ of them using smartphones. Most of these customers are young, knowledgeable and experienced. They prefer new payment methods, especially those built on mobile platforms, making payment connection easy and convenient without cash or card. Therefore, mobile payment is more and more developed in Vietnam.

In ThanhHoa, the development of mobile banking service is still not corresponding to commercial bank's potential and smartphone development. The study in the factors affecting the decisions of using mobile banking in ThanhHoa aims to help commercial banks have a scientific basis and from which propose solutions for developing. 


\section{Literature Review}

The affecting factors which influence on the intention and behavior of using mobile banking service are studied abroad but it is not the same in Vietnam. First of all, it can be mentioned some typical abroad studies such as: By using the Innovation Diffusion Theory (IDT) and the Decomposed Theory of Planned Behavior (DTPB), Brown, Cajee, Davies, and Stroebel (2003) surveyed 162 people and found that the advantage of opportunity to experience Mobile banking, the number of offered services and perceived risk are factors significantly affecting its users. Lee, McGoldrick, Keeling, and Doherty (2003), conducted 8 interviews to collect score sheets from the participants and concluded that relative advantage and compatibility are factors positively affecting the use of Mobile banking and the perceived risk is a factor negatively affecting it.

It is shown in the survey-based study of 128 people randomly interviewed on the streets by Laforet and Li (2005) that the consumers' perception significantly affects their application of online banking and Mobile banking and it is increased thank to the mass media other than oral method. Luarn and Lin (2005) used the Extended Technology Acceptance Model (TAM) to understand the intention and behavior of using mobile baking, accordingly, they raised questions and collected the answers of 180 people in Taiwan and then concluded that self-perception, perceived financial costs, perceived prestige, perceived ease of use and perceived usefulness have a positive effect on the intention and behavior of using mobile baking. Similarly, Amin, Hamid, Lada, and Anis (2008) also used the Extended Technology Acceptance Model (TAM), including five structures - perceived usefulness, perceived ease of use, perceived reliability, volume of information and applied technologies to study the application of Mobile banking. They gathered 158 valid questionnaires in Malaysia and found that perceived usefulness, perceived ease of use, perceived trust, information and applied technologies have significantly affected the intention to use the service.

Yang (2009) surveyed 178 students from one of the largest universities in Southern Taiwan and found that transaction speeds and especially reduced transaction fees would encourage people to use mobile banking. By conducting an experimental study, Karjaluoto, Riquelme, and Rios (2010) surveyed 681 Singaporean consumers and concluded that perceived usefulness, perceived social norms and perceived risks (in order of influence) are three important factors affecting the application of Mobile banking. Koenig-Lewis, Palmer, and Moll (2010) gathered the answers of 155 customers of 18 to 35 years old in Germany and found that perceived usefulness, compatibility and perceived risk are important for customers, who wanted to use mobile banking.
Sripalawat, Thongmak, and Ngramyarn (2011) gathered the answers of 195 people and found that subjective indicators are the most influential factor, the usefulness is the second influencing factor and the efficiency is the third factor affecting the use of Mobile banking. By gathering 325 valid responses from MBA students in India, Dasgupta, Paul, and Fuloria (2011) firstly analyzed exploratory factors to identify 7 premises for intention and behavior of tending to mobile baking application. They then used regression technique to examine these premises' impact on the intention and behavior. Their experimental results supported 6 among 7 premises (except the perceived risk). 6 premises including perceived visual, perceived usefulness, perceived ease of use, perceived value, perceived confidence, and perceived trust and tradition have had a significant influence on the intention and behavior of using mobile baking service.

In Vietnam, there have also been those, who study the factors affecting technology-based services such as Thanh and Thi (2011). It is also shown in these studies the factors differently affecting use behaviors in different fields. However, mobile baking is less studied than others at banks.

In short, mobile banking so far is not a new field of study but it has been studied by many researchers at home and abroad. In foreign countries, there are many studies on this field, however, they are conducted in different contexts and also produce different conclusions regarding the impact of factors on the acceptance and use of mobile banking. In Vietnam, mobile banking is less studied; almost studies are characterized by only subjective assessments but not extensively conducted using quantitative method.

\section{Research Methods and Materials}

\subsection{Theoretical Background}

Over the past two decades, many researchers have used the technology acceptance model (TAM) developed by Davis (1989) to explain an individual's acceptance of new information technology (IT) and verify that perceived usefulness and ease of use are important personal acceptance structures. The TAM theory is considered as fundamental theory for the studies on modeling the unified theory of acceptance and use of technology in the future. Therefore, this study is also based on the unified theory of acceptance and use of technology (TAM).

The unified theory of acceptance and use of technology (UTAUT) was developed by Venkatesh, Morris, Davis, and Davis (2003). UTAUT theory is not widely used but has some advantages compared to others (Yu, 2012). It is integrated the essential advantages of the elements in the above models. After considering the impact of the factors on the intention and behavior of using, it can be seen the 
differences based on exterior factors (gender, qualification, age, experience, voluntariness) in this model and it has been also tested to demonstrate its superiority over other models (Venkatesh et al., 2003; Park, Yang, \&Lehto, 2007).

\subsection{Research Models and Hypotheses}

\subsubsection{Research Models}

Basing on the actual business conditions in some ThanhHoa commercial banks and inheriting the theoretical bases of TAM and UTAUT, the authors propose a model that is based on some integrated elements of the above models (Figure 1).

It is hypothesized in the study that factors affecting mobile banking acceptance and use include:

(1) Performance expectance: Is an extent, to which people believe that mobile banking use will help them work more effectively.

(2) Perceived ease of use: Is an extent, to which people believe that it is easy to log in and use mobile banking.

(3) Social influence: Means that an individual, who perceives and will use mobile banking, is strongly influenced by surrounding people.

(4) Perceived trust: Is a degree of confidence that an organization will handle all transactions safely and keep personal information secret.

(5) Compatibility: Is an external environment that helps users overcome barriers to use a new information technology industry.

(6) Perceived transaction costs: Are the level of trust in the costs for using mobile baking.

(7) Behavioral intention: Is a customer's willingness to accept and use mobile banking.

(8) Level of use: Is the regular use of mobile banking services by a customer.

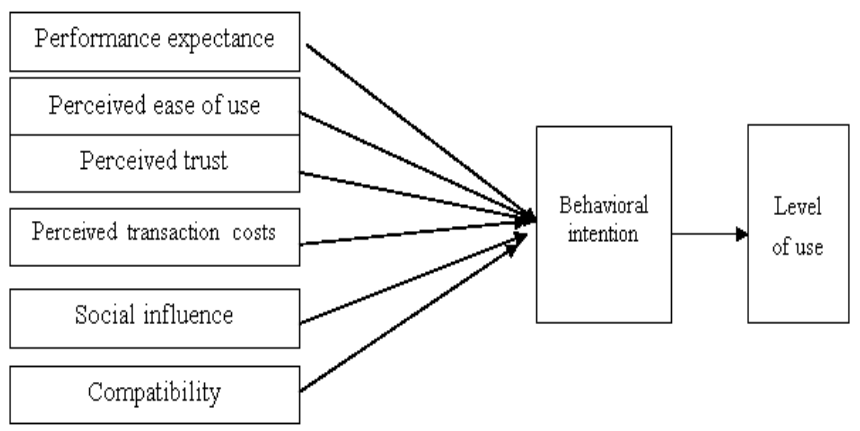

Figure 1: Model proposed by the authors

\subsubsection{Study Hypotheses}

H1: Performance expectance has a positive effect on the intention to use mobile banking

H2: Perceived ease of use has a positive effect on the intention to use mobile banking
H3: Perceived trust has a positive effect on the intention to use mobile banking

H4: Perceived transaction costs have has a negative effect on the intention to use mobile banking

H5: Social influence has a positive effect on the intention to use mobile banking

H6: Compatibility has a positive effect on the intention to use mobile banking

H7: Behavioral intention has a significant impact on the level of using mobile baking service

\subsection{Description of Study Data}

\subsubsection{Subjects of Study}

The subjects of study are those, who have not yet used and are using mobile baking service in ThanhHoa, irrespective of age, gender, income and qualification.

\subsubsection{Scope of Study Sample}

According to Hair, Anderson, Tatham, and Black (1998), the sample size affects the generality of the study results by the ratio of observed variables to the independent variables and there should be 5 observed variables for each independent variable in the difference. In order to reach the desired level of the study and achieve the generalized results, there must be 15-20 observations per an independent variable. This study consists of 6 independent variables so it is necessary to have at least 120 observations.

\subsubsection{Survey Method}

A survey is conducted with a questionnaire and in the manner of directly surveyed customers in apartment areas, sending votes at the transaction counters in ThanhHoa or through relatives and friends.

\subsubsection{Questionnaire}

For this study, the author designs a questionnaire consisting of three parts:

Part 1: General information.

Part 2: The surveyed people's perception of the factors affecting the intention to use mobile banking in ThanhHoa.

Part 3: The surveyed people's answers about their intention to use mobile banking and the level of using the service in ThanhHoa.

\section{Results}

\subsection{Descriptive Statistics}

Descriptive statistics are based on 370 distributed votes and 336 valid collected ones, in particular, customers, who have not yet used and have already used mobile baking 
service in ThanhHoa, account for 141 and 195 votes respectively. Demographic characteristics of the surveyed people are specified as Table 1 follows:

Table 1: Description of demographic characteristics of the surveyed sample

\begin{tabular}{|c|c|c|c|c|c|c|}
\hline \multirow{2}{*}{ Content } & \multicolumn{2}{|c|}{$\begin{array}{c}\text { Not yet used mobile } \\
\text { baking }\end{array}$} & \multicolumn{2}{|c|}{$\begin{array}{l}\text { Currently using } \\
\text { mobile baking }\end{array}$} & \multicolumn{2}{|r|}{ Total } \\
\hline & Votes & $\begin{array}{c}\text { Percentage } \\
(\%)\end{array}$ & Votes & \begin{tabular}{|c} 
Percentage \\
$(\%)$
\end{tabular} & Votes & \begin{tabular}{|c} 
Percentag \\
e (\%)
\end{tabular} \\
\hline \multicolumn{7}{|c|}{ Gender } \\
\hline Male & 118 & 60,5 & 65 & 46,1 & 183 & 59,0 \\
\hline Female & 77 & 39,5 & 76 & 53,9 & 153 & 41,0 \\
\hline \multicolumn{7}{|l|}{ Age } \\
\hline $\begin{array}{l}\text { Less than } \\
30 \text { years } \\
\text { old }\end{array}$ & 47 & 24,1 & 27 & 19,1 & 74 & 22 \\
\hline $\begin{array}{l}\text { From } 30 \text { to } \\
\text { less than } \\
40 \text { years } \\
\text { old }\end{array}$ & 56 & 28,7 & 43 & 30,5 & 99 & 29,5 \\
\hline $\begin{array}{c}\text { From } 40 \text { to } \\
\text { less than } \\
50 \text { years } \\
\text { old }\end{array}$ & 49 & 25,1 & 37 & 26,2 & 86 & 25,6 \\
\hline $\begin{array}{c}50 \text { years } \\
\text { old and } \\
\text { over }\end{array}$ & 43 & 22,1 & 34 & 24,1 & 77 & 22,9 \\
\hline \multicolumn{7}{|c|}{ Occupation } \\
\hline Student & 16 & 8,2 & 11 & 7,8 & 27 & 8 \\
\hline $\begin{array}{c}\text { State } \\
\text { officials }\end{array}$ & 42 & 21,5 & 41 & 29,1 & 83 & 24,7 \\
\hline $\begin{array}{l}\text { Armed } \\
\text { force }\end{array}$ & 33 & 16,9 & 22 & 15,6 & 55 & 16,4 \\
\hline Businessmen & 51 & 26,2 & 37 & 26,2 & 88 & 26,2 \\
\hline $\begin{array}{c}\text { Free } \\
\text { workers }\end{array}$ & 19 & 9,7 & 12 & 8,5 & 31 & 9,2 \\
\hline $\begin{array}{l}\text { Financial } \\
\text { field }\end{array}$ & 24 & 12,8 & 11 & 7,8 & 36 & 10,7 \\
\hline Others & 9 & 4,6 & 7 & 5,0 & 16 & 4,8 \\
\hline \multicolumn{7}{|c|}{ Area } \\
\hline City & 187 & 95,9 & 17 & 12,1 & 204 & 60,7 \\
\hline countryside & 8 & 4,1 & 124 & 87,9 & 132 & 39,3 \\
\hline \multicolumn{7}{|c|}{ Commercial Bank } \\
\hline Agribank & 8 & 4,1 & 13 & 9,2 & 21 & 6,3 \\
\hline $\begin{array}{l}\text { Vietcomba } \\
\text { nk }\end{array}$ & 21 & 10,8 & 13 & 9,2 & 34 & 10,1 \\
\hline $\begin{array}{l}\text { Teckcomba } \\
\text { nk }\end{array}$ & 28 & 14,4 & 23 & 16,3 & 51 & 15,2 \\
\hline BIDV & 12 & 6,2 & 14 & 9,9 & 26 & 7,7 \\
\hline Vpbank & 18 & 9,2 & 15 & 10,6 & 33 & $\mathbf{9 , 8}$ \\
\hline Vietinbank & 15 & 7,7 & 6 & 4,3 & 21 & 6,3 \\
\hline VIB & 17 & 8,7 & 14 & 9,9 & 31 & 9,2 \\
\hline ACB & 21 & 10,8 & 13 & 9,2 & 34 & 10,1 \\
\hline Seabank & 17 & 8,7 & 10 & 7,1 & 27 & 8 \\
\hline $\begin{array}{c}\text { Pvcomban } \\
k\end{array}$ & 9 & 4,6 & 6 & 4,3 & 15 & 4,5 \\
\hline Others & 29 & 14,9 & 14 & 9,9 & 43 & 12,8 \\
\hline
\end{tabular}

\subsection{Analysis of the Factors Affecting Mobile Banking in ThanhHoa}

\subsubsection{Test of the Reliability of Scale}

One of the popular methods for testing the reliability of a scale is to test the Cronbach's Alpha coefficient. Cronbach's Alpha coefficient will be run separately for each independent factor, thereby measuring the consistency among the variables of the same factor because the higher and higher the consistency of observed variables is, the higher and higer the reliability of the scale is. In this study, each factor, when being tested, must have Cronbach's Alpha score of 0.6 and over to be considered acceptable. If the factor's Cronbach's Alpha score reaches from 0.7 to 0.8, it can be used and if it ranges from 0.8 to 1 , the reliability is high (Hair et al., 1998).

Meanwhile, the item-total correlation coefficient of each variable must reach 0.3 and over to be included in the next analysis (Nunnally \& Bernstein, 1994). The variables, the coefficient of which is less than 0.3 , will be considered as non-informative variable and excluded before the factor analysis.

The analysis results of the scale reliability using Cronbach's Alpha coefficient indicate that the values of the factor groups ranges from 0.762 to 0.931 . The item-total correlation coefficient is greater than 0.3 . Thus, it can be seen in the above results of the data survey that the information evaluated by customers is quite sufficient and reliable to be used for the next analysis.

The results of the reliability analysis of the scales using the Cronbach's Alpha coefficient of the factor groups are from 0.781 to 0.928 . Item-total correlation coefficient of PTC4 $=0,251<0.3$ and cronbach's alpha coefficient of observed variable PE3, PEU2 has cronbach's alpha if item deleted is greater than current cronbach's alpha coefficient, no Guaranteed reliability for analysis. For affirmative analysis and SEM structure, it may not be necessary to analyze reliability before exploratory factor analysis. Because after confirming the author's factor will recalculate the reliability of the scale. Therefore, the author still uses variables PE3, PEU2, PTC4 for discovering factor analysis to conduct affirmative analysis and type of variables in the discovery analysis section. Thus, with the results on the data survey, the information assessed by customers is quite complete and reliable when used for the next analysis.

\subsubsection{Analysis of Exploratory Factor}

Principal Axis Factoring method with Promax rotation (Gerbing \& Anderson, 1988) and loading coefficient $\geq 0.5$ (Hair et al., 1998) is used for both independent and dependent variables. Bartlett test is performed to consider the hypothesis of correlation among the observed variables. 


\section{Analysis results of the first exploratory factor}

It is shown in the analysis results of the firstly exploratory factor that Cumulative of Variance is $77,118 \%$ (> 50\%) and $\mathrm{KMO}$ is $0,830(>0.5)$ and Bartlett test is statistically significant (Sig. $<0.05)$ so EFA analysis is appropriate.

In addition, it is also shown in the EFA results that the variables PE3, PTC4, PEU2 have loading coefficients of less than 0.5 so they are excluded from the factor analysis.

Table 2: Analysis result of the second exploratory factor

\begin{tabular}{|c|c|c|c|c|c|c|c|c|}
\hline \multicolumn{9}{|c|}{ Pattern Matrix } \\
\hline & \multicolumn{8}{|c|}{ Factor } \\
\hline & 1 & 2 & 3 & 4 & 5 & 6 & 7 & 8 \\
\hline $\mathrm{CO} 4$ & .962 & & & & & & & \\
\hline $\mathrm{CO3}$ & .837 & & & & & & & \\
\hline $\mathrm{CO} 2$ & .792 & & & & & & & \\
\hline CO1 & .788 & & & & & & & \\
\hline SI2 & & .920 & & & & & & \\
\hline SI3 & & .869 & & & & & & \\
\hline SI1 & & .759 & & & & & & \\
\hline SI4 & & .688 & & & & & & \\
\hline PE1 & & & 940 & & & & & \\
\hline $\begin{array}{l}\text { PE4 } \\
\end{array}$ & & & 939 & & & & & \\
\hline PE2 & & & .916 & & & & & \\
\hline BU1 & & & & .958 & & & & \\
\hline BU2 & & & & .868 & & & & \\
\hline BU3 & & & & \begin{tabular}{|l|l|}
.812 \\
\end{tabular} & & & & \\
\hline PT2 & & & & & .957 & & & \\
\hline PT1 & & & & & .914 & & & \\
\hline PT3 & & & & & .819 & & & \\
\hline PTC2 & & & & & & 974 & & \\
\hline PTC1 & & & & & & .946 & & \\
\hline PTC3 & & & & & & .668 & & \\
\hline PEU4 & & & & & & & \begin{tabular}{|l|}
.930 \\
\end{tabular} & \\
\hline PEU3 & & & & & & & .848 & \\
\hline PEU1 & & & & & & & .755 & \\
\hline BI2 & & & & & & & & .918 \\
\hline BI3 & & & & & & & & .875 \\
\hline BI1 & & & & & & & & .856 \\
\hline $\begin{array}{l}\text { Eigen } \\
\text { values }\end{array}$ & 7,016 & 3,628 & 2,693 & 2,347 & 1,969 & 1,698 & 1,418 & 1,056 \\
\hline \multicolumn{9}{|c|}{ KMO: 0.832} \\
\hline Cumulat & ive of & rianc & 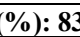 & & & & & \\
\hline
\end{tabular}

\section{Analysis results of the second exploratory factor}

It is shown in the analysis results of the second exploratory factor that all variables have loading coefficient of more than 0.5. Cumulative of Variance is $83,942 \%(>50 \%)$ and $\mathrm{KMO}$ is $0,832(>0,5)$ and Bartlett test is statistically significant (Sig.<0.05) so EFA analysis is appropriate.

It is shown in the second EFA results the following factors:

Factor 1: includes the observed variables $\mathrm{CO} 1-\mathrm{CO} 4$ and is named "Compatibility" (CO).

Factor 2: includes observed variables SI1-SI4 and is named "Social influence" (SI).

Factor 3: includes observed variables PE1-PE4 (except PE3) and is named "Performance Expectance" (PE).

Factor 4: includes observed variables PTC1-PTC3 (except PTC4) and is named "Perceived transaction costs" (PTC).
Factor 5: includes observed variables PT1-PT3 is named "Perceived trust" (PT).

Factor 6: includes observed variables PEU1-PEU4 (except PEU2) is named "Perceived ease of use" (PEU).

Factor 7: includes observed variables "BI1-BI3" is named "Behavioral Intention" (BI).

Factor 8: includes observed variables "BU1-BU3" is named "Behavior of using" (BU)

After EFA exploratory analysis, it can be seen that the model have no difference from the research model, only some observed variables are unreliable so they are excluded from the study variable. There is no new factor group as Table 2 follows:

\subsubsection{Analysis of Confirmatory Factor}

It can be seen in the EFA results that there are eight key concepts in the research model. To measure the model's suitability with market information, we use Chi-square (CMIN), which is adjusted by degrees of freedom (CMIN/df), CFI, GFI, TLI and RMSEA indices. The model is considered to be suitable with the market data when it receives TLI, CFI $\geq 0.9$; GFI $\geq 0.8$ (Bentler \& Bonelt, 1980), $\mathrm{CMIN} / \mathrm{df} \leq 3$ (Carmines \& McIver, 1981) RMSEA $\leq 0.08$ (Steiger, 1990). It is shown in the CFA results of the research model that it is suitable with the market information (Figure 2). P-value results of the observed variables representing the factors all have the value sig. = 0.000 so the observed variables are affirmatively considered to have good representation for the CFA model factor. The correlation coefficient of each pair of concepts is different from 1 in the reliability of $95 \%$ (P-Value value $=0.000)$ so the concepts achieve discriminant value. The weights (normalized) all are more than 0.5 and weights (nonnormalized) are statistically significant (sig. $<0.000$ ) so the concepts achieve convergence value. This measurement model is compatible with market data and there is no correlation among measurement errors so it achieves uniqueness.

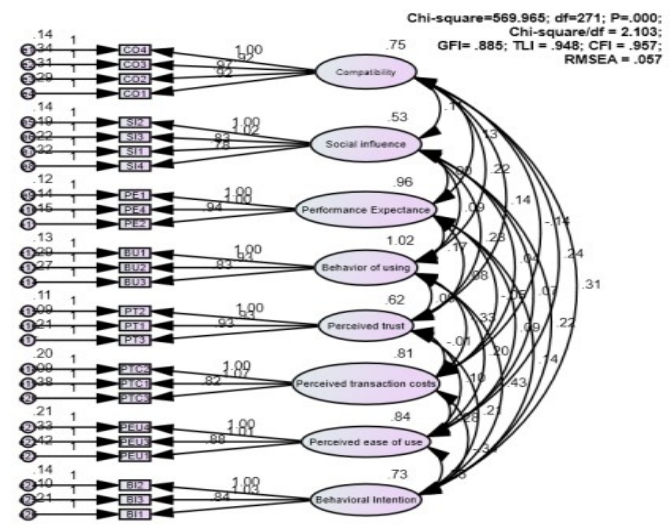

Figure 2: Non-standardized CFA chart of the research model 


\subsubsection{Test of Reliability after Exploratory Factor Analysis}

It can be seen after Cronbach's Alpha test that Cronbach's Alpha coefficient of each factor has a value of more than 0.7 and the item-total correlation coefficient is more than 0.3 , therefore, the scales all are reliable. The combined reliability and Average Variance Extracted of each factor have values greater than 0.5 (Table 3) so the factors in the model are reliable.

Table 3: Test results of reliability of the scale

\begin{tabular}{|c|c|c|c|c|c|}
\hline Factor & $\begin{array}{c}\text { Number } \\
\text { of } \\
\text { observed } \\
\text { variables }\end{array}$ & $\begin{array}{c}\text { Cronbach's } \\
\text { Alpha } \\
\text { reliability }\end{array}$ & $\begin{array}{c}\text { Combined } \\
\text { reliability } \\
\text { (CR) }\end{array}$ & $\begin{array}{c}\text { Average } \\
\text { Variance } \\
\text { Extracted } \\
\text { (AVE) }\end{array}$ & $\begin{array}{c}\text { Convergenc } \\
\text { e and } \\
\text { discriminan } \\
\text { t values }\end{array}$ \\
\hline $\begin{array}{c}\text { Compatibility } \\
\text { (CO) }\end{array}$ & 4 & 0,908 & 0,812 & 0,521 & Satisfactory \\
\hline $\begin{array}{c}\text { Social } \\
\text { influence (SI) }\end{array}$ & 4 & 0,884 & 0,763 & 0,453 & Satisfactory \\
\hline $\begin{array}{c}\text { Performance } \\
\text { Expectance } \\
\text { (PE) }\end{array}$ & 3 & 0,952 & 0,903 & 0,757 & Satisfactory \\
\hline $\begin{array}{c}\text { Perceived } \\
\text { transaction } \\
\text { costs (PTC) }\end{array}$ & 3 & 0,903 & 0,817 & 0,605 & Satisfactory \\
\hline $\begin{array}{c}\text { Behavior of } \\
\text { using (BU) }\end{array}$ & 3 & 0,876 & 0,754 & 0,508 & Satisfactory \\
\hline $\begin{array}{c}\text { Perceived } \\
\text { trust }\end{array}$ & 3 & 0,923 & 0,848 & 0,652 & Satisfactory \\
\hline $\begin{array}{c}\text { Behavioral } \\
\text { Intention (BI) }\end{array}$ & 3 & 0,928 & 0,855 & 0,665 & Satisfactory \\
\hline $\begin{array}{c}\text { Perceived } \\
\text { ease of use } \\
\text { (PU) }\end{array}$ & 3 & 0,914 & 0,830 & 0,621 & Satisfactory \\
\hline
\end{tabular}

\subsubsection{Structural Equation Modeling (SEM)}

It is shown in the SEM analysis results that all the values are satisfactory. So the model is completely suitable with the market data and can be used to test the expected relationships stated in the hypothetical model (Figure 3).

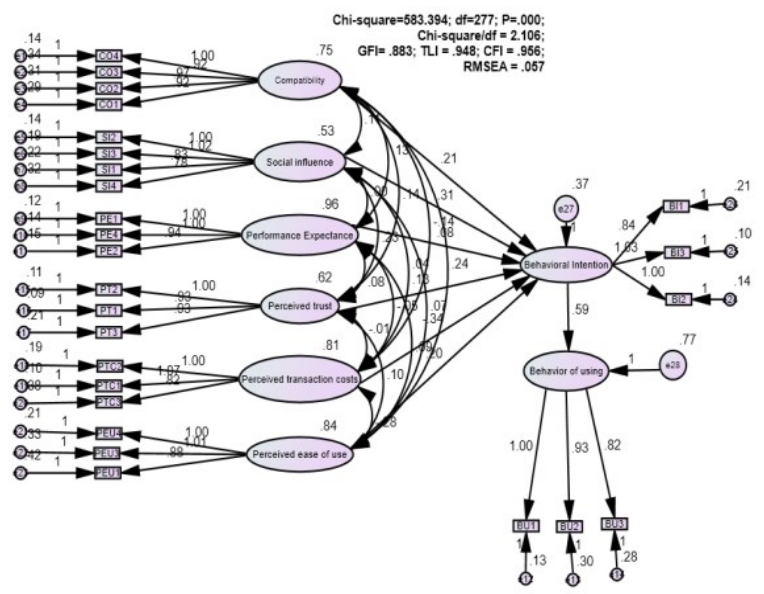

Figure 3: Non-standardized Structural Equation Modeling (SEM)
It is shown in the results of tabular data on the model's regression coefficient that all factors have the value sig. of less than 0.05 . The factor "perceived cost" has opposite impact $(-0,338)$ and the remaining factors all have positive impact on the intention to use mobile banking. At the same time, the intention and behavior also have positive impact on the use of mobile banking in Thanh Hoa commercial banks (Table 4).

Table 4: Coefficients of regression model SEM

\begin{tabular}{|c|c|c|c|c|}
\hline Factor & Estimate & S.E. & C.R. & P-value \\
\hline $\mathrm{CO} \rightarrow \mathrm{BI}$ & 0,206 & 0,048 & 4,272 & $* * *$ \\
\hline $\mathrm{PE} \rightarrow \mathrm{BI}$ & 0,076 & 0,039 & 1,984 & 0,047 \\
\hline $\mathrm{PT} \rightarrow \mathrm{BI}$ & 0,130 & 0,054 & 2,414 & 0,016 \\
\hline $\mathrm{PTC} \rightarrow \mathrm{BI}$ & $-0,338$ & 0,047 & $-7,237$ & $* * *$ \\
\hline $\mathrm{PEU} \rightarrow \mathrm{BI}$ & 0,197 & 0,048 & 4,097 & $* * *$ \\
\hline $\mathrm{SI} \rightarrow \mathrm{BI}$ & 0,313 & 0,060 & 5,238 & $* * *$ \\
\hline $\mathrm{BI} \rightarrow \mathrm{BU}$ & 0,594 & 0,063 & 9,434 & $* * *$ \\
\hline
\end{tabular}

*Estimated to have been standardized

Test results of hypotheses are shown in the following table 5:

Table 5: Test results of the model's hypotheses

\begin{tabular}{|c|c|c|}
\hline Hypothesis & Content & Result \\
\hline H1 & $\begin{array}{c}\text { Performance Expectance has a positive } \\
\text { effect on the intention to use mobile } \\
\text { banking }\end{array}$ & Acceptable \\
\hline H2 & $\begin{array}{c}\text { Perceived ease of use has a positive } \\
\text { effect on the intention to use mobile } \\
\text { banking }\end{array}$ & Acceptable \\
\hline H3 & $\begin{array}{c}\text { Perceived trust has a positive effect on } \\
\text { the intention to use mobile banking }\end{array}$ & Acceptable \\
\hline H4 & $\begin{array}{c}\text { Perceived transaction cost has a } \\
\text { negative effect on the intention to use } \\
\text { mobile banking }\end{array}$ & Acceptable \\
\hline H5 & $\begin{array}{c}\text { Social Influence has a positive effect on } \\
\text { the intention to use mobile banking }\end{array}$ & Acceptable \\
\hline H6 & $\begin{array}{c}\text { Facilitating Conditions has a positive } \\
\text { effect on the intention to use mobile } \\
\text { banking }\end{array}$ & Acceptable \\
\hline H7 & $\begin{array}{c}\text { Behavioral Intention has a positive } \\
\text { effect on the intention to use mobile } \\
\text { banking }\end{array}$ & Acceptable \\
\hline
\end{tabular}

(1) Among the positive factors, the social influence has the strongest effect $(0,313)$, the second is the Compatibility $(0,206)$, the third is the Perceived ease of use $(0,197)$, and the next is perceived trust $(0,130)$. The performance expectance has the lowest impact on the intention to use mobile banking in ThanhHoa.

(2) The perceived cost has the opposite effect and the largest impact coefficient $(-, 338)$ on the intention to use mobile banking in ThanhHoa. 


\section{Recommendations}

\subsection{Exploiting the Advantages of Social Influence}

Social influence is the influence created by the surrounding people when they share the information about use of mobile banking service. Accordingly, banks need to consider the factor to increase the number of potential customers and the use of the existing customers. In particular, for the people currently using the mobile banking service, the banks should communicate the convenience as well as the benefits that a mobile banking user can receive. They will be an important channel of giving advice to their relatives about the use of mobile banking. Moreover, the banks may issue incentive policies for those, who introduce their friends and relatives to register to the mobile banking service (for example, gifts for both introducing and introduced people). For the people having not used any banking service yet, the banks should share about the use of mobile banking on social networks such as Facebook, Zalo and so on or in conferences and seminars in the financial and banking fields.

\subsection{Increasing Compatibility and Minimizing Costs for Customers}

According to the survey results, the factors that prevent customers from using the mobile banking service are the fact that they do not have smartphones, do not register the internet, and internet access cost is high. Therefore, it is necessary for the banks to have necessary support in term of transaction costs, for example, minimizing the costs of money transfer services, connecting with service providers to freely provide or deduct money for customers when they make payment via mobile banking. In addition, the banks should issue policies suitable for each target customer and collect no charge from customers newly registering to use the service.

Moreover, banks need to expand cooperation with a variety of service providers to deploy payments on Mobile Banking, Mobile Payment and allow customers to register Mobile Banking on electronic channels such as: Internet Banking, Phone Banking, USSD, Digital Branches and so forth or even at stores that have cooperated with it.

\subsection{Developing a Strategy to Increase the Users' Perceived Ease of Use}

Increasing the perceived ease of use for customers will help to increase the level of acceptance and use of this service using the following solutions:

Firstly, it is necessary for the banks to pay attention to the value of experience and increase the utilities for customers.
It will be a "golden key" to optimally exploit the Mobile Banking service because, according to the analysis of Varoli Corporation, $52 \%$ among total smartphone and tablet users has downloaded the Mobile Banking application and about $40 \%$ of them said that they have thought about deleting the application because of their dissatisfaction with it. By providing quality services and products and with an attentive service attitude and a precise and quick process, customers will feel to have a good experience and be interested in the bank and since then have stronger attachment with the bank and introduce it to their relatives and friends.

Secondly, it is also necessary for the banks to improve the quality of services to increase the perceived ease of use by its customers and design a simple, easy-to-use, user-friendly, easy-to-read and easy-to-understand interface. The banks should put forward specific instructions to the use of mobile banking (from setting-up, logging-in to transaction execution). These instructions can be placed on the counter or Facebook. Bank staffs are available and ready to answer customers' questions in the process of transaction.

\subsection{Issuing a Policy on Increasing the Security of Mobile Banking System}

The banks should pay attention to increase the security of Mobile Banking system through Mobile Banking forms of higher security such as SMS Banking Application, WAP or Mobile Client Applications. At the same time, the banks should use multi-factor authentication in combination with data encryption and keep confident using biometric technology: fingerprints, combined eyes. The banks should use a two-factor security measure for all 4 Mobile Banking forms when having authentication servers participating in the process of authentication and data security for Mobile Banking.

In order to increase the security of Mobile Banking service, during the transactions, the messages need to be encrypted in combination with the use of other security measures such as additional PIN identification or one-time password OTP. In addition, this transaction can still be more secured by another security measure of Matrix - Password.

\subsection{Developing an Individual Customer Management System}

To deploy a customer management system, the banks can research the following solutions:

Firstly, it is deployed a information management program with regard to the customers, who use products and services including: Opening an account, issuing a card, using Mobile Banking service, Agribank E-Mobile, Internet Banking, Paying via account, Overdrawing, Electricity costs and then 
updated all the information about customers' products and services to the management program.

Secondly, it is deployed a customer relationship management system, accordingly, the detailed information about the number of customers using each type of service (Account, card issuance, use of Mobile Banking, Agribank E-Mobile, Internet Banking, Payment via account, Overdrawing, Electricity costs) of each branch in the province is monitored..

\section{References}

Amin, H., Hamid, M. R. A., Lada, S., \& Anis, Z. (2008). The adoption of mobile banking in Malaysia: The case of Bank Islam Malaysia Berhad. International Journal of Business and Society, 9(2), 43-53.

Barnes, S. J., \& Corbitt, B. J. (2003). Mobile banking: Concept and potential. International Journal of Mobile Communications, 1(3), 273-288.

Brown, I., Cajee, Z., Davies, D., \& Stroebel, S. (2003). Cell phone banking: predictors of adoption in South Africaan exploratory study. International journal of information management, 23(5), 381-394. https://doi.org/10.1016/S0268-4012(03)00065-3

Bentler, P. M., \& Bonett, D. G. (1980). Significance tests and goodness of fit in the analysis of covariance structures. Psychological Bulletin, 88(3), 588-606. Retrieved from https://psycnet.apa.org/record/198106898-001

Carmines, E. G., \& Mclver, J. D. (1981).Analyzing models with unobserved variables: Analysis of covariance structures. In G. W. Bohinstedt \& E. F. Borgatta (Eds.), Social measurement: Current issues (pp. 65-115). Beverly Hills, CA: Sage.

Dasgupta, S., Paul, R. I. K., \& Fuloria.S. (2011). Factors affecting behavioral intentions towards mobile banking usage: Empirical evidence from India. Romanian Journal of Marketing, 3(1), 6-28

Davis, F. D. (1989). Perceived usefulness, perceived ease of use, and user acceptance of information technology. MIS Quarterly, 13(3), 319-340. Retrieved from https://www.jstor.org/stable/249008

Gerbing, D. W., \& Anderson, J. C. (1988).An updated paradigm for scale development incorporating unidimensionality and its assessment. Journal of Marketing Research, 25(2), 186-192. https://doi.org/10.1177/002224378802500207

Hair, J. F., Anderson, R. E., Tatham, R. L., \& Black, W. (1998). Multivariate Data Analysis (5th Ed., pp. 577644). Upper Saddle River, NJ: Prentice Hall.

Koenig-Lewis, N., Palmer, A., \& Moll, A. (2010).Predicting young consumers' take up of mobile banking services.
International Journal of Bank Marketing, 28(5), 410-432. https://doi.org/10.1108/02652321011064917

Karjaluoto, H., Riquelme, H. E., \& Rios, R. E. (2010). The moderating effect of gender in the adoption of mobile banking. International Journal of bank marketing, 28(5), 328-341. https://doi.org/10.1108/02652321011064872

Laforet, S., \& Li, X. (2005). Consumers' attitudes towards online and mobile banking in China. International Journal of Bank Marketing, 23(5), 362-380. https://doi.org/10.1108/02652320510629250

Lee, M. S., McGoldrick, P. J., Keeling, K. A., \& Doherty, J. (2003).Using ZMET to explore barriers to the adoption of $3 \mathrm{G}$ mobile banking services. International Journal of Retail \& Distribution Management, 31(6), 340-348. https://doi.org/10.1108/09590550310476079

Luarn, P., \& Lin, H. H. (2005). Toward an understanding of the behavioral intention to use mobile banking. Computers in Human Behavior, 21(6), 873-891. https://doi.org/10.1016/j.chb.2004.03.003

Nunnally, J. C., \& Burnstein, I. H (1994). PschyChometric Theory (3rd Edition). New York, NY: McGraw-Hill, Inc.

Park, J., Yang, S., \& Lehto, X. (2007). Adoption of mobile technologies for Chinese consumers. Journal of Electronic Commerce Research, 8(3), 196-206.

Sripalawat, J., Thongmak, M., \& Ngramyarn, A. (2011). Mbanking in metropolitan Bangkok and a comparison with other countries. Journal of Computer Information Systems, 51(3), 67-76. doi: $10.1080 / 08874417.2011 .11645487$

Steiger, J. H. (1990). Structural model evaluation and modification: An interval estimation approach. Multivariate Behavioral Research, 25(2), 173-180. https://doi.org/10.1207/s15327906mbr2502_4

Thanh, N. D., \& Thi, C. H. (2011). Proposing the E Banking adopting model in Vietnam. Science and Technology Development Journal, 14(2), 97-105. Retrieved from

http://www.vjol.info/index.php/JSTD/article/viewArticle $/ 8643$

Venkatesh, V., Morris, M. G., Davis, G. B., \& Davis, F. D. (2003). User acceptance of information technology: Toward a unified view. MIS Quarterly, 27(3), 425-478. doi: $10.2307 / 30036540$

Yang, A. S. (2009). Exploring adoption difficulties in mobile banking services. Canadian Journal of Administrative Sciences/Revue Canadienne des Sciences de l'Administration, 26(2), 136-149. https://doi.org/10.1002/cjas.102

$\mathrm{Yu}$, C. S. (2012). Factors affecting individuals to adopt mobile banking: Empirical evidence from the UTAUT model. Journal of Electronic Commerce Research, 13(2), 104-121. 